\title{
The potential of plantations of Terminalia superba Engl. \& Diels for wood and biomass production (Mayombe Forest, Democratic Republic of Congo)*
}

\author{
Maaike DE RIDDER ${ }^{1,2 * *}$, Wannes HubAU ${ }^{1,2}$, Jan VAN DEN BULCKE $^{1}$, Joris VAN AcKER ${ }^{1}$, \\ Hans BEECKMAN ${ }^{2}$ \\ ${ }^{1}$ Ghent University, Laboratory of Wood Technology, Coupure Links 653, 9000 Ghent, Belgium \\ ${ }^{2}$ Royal Museum for Central Africa, Laboratory for Wood Biology and Xylarium, Leuvensesteenweg 13, 3080 Tervuren, Belgium
}

(Received 26 June 2009; accepted 19 November 2009)

Keywords:

Terminalia superba /

Central Africa /

plantation /

volume /

biomass

\begin{abstract}
- In the 1940s-1950s, large limba (Terminalia superba Engl. \& Diels) plantations were established in the Democratic Republic of Congo to reduce the pressure on the natural forests.

- The objective of this study was to evaluate the potential of these long-rotation plantations as production forests (timber) and carbon sinks.

- Five different plantations, between 50 and 58 years old, were sampled. Over a sample surface of more than 73 ha, the diameter above buttresses of 2680 trees, bole height of 265 trees and tree height of 128 trees was measured.

- To estimate the commercial volume, a nonlinear power law regression was used $\left(R^{2}=0.95\right)$. A power law variance function was applied to counter heteroscedasticity of the residual plot. Estimates of commercial tree and stand volume at 50 to $58 \mathrm{y}$ were $5.6 \pm 4.1 \mathrm{~m}^{3}$ and $183.9 \pm 135.0 \mathrm{~m}^{3} \mathrm{ha}^{-1}$. Stand volumes appear low but are explained by a large decrease in tree density. However, the mean volume increment of 3.2-3.7 $\mathrm{m}^{3} \mathrm{ha}^{-1} \mathrm{y}^{-1}$ corresponds well with teak plantations of a similar age. For limba, aboveground biomass and carbon estimates of this study (resp. 108.4 and $54.2 \mathrm{Mg} \mathrm{ha}^{-1}$ ) differ significantly from those of existing aboveground biomass models (resp. 135.7-143.9 $\mathrm{Mg} \mathrm{ha}^{-1}$ biomass and 67.9-72.0 $\mathrm{Mg} \mathrm{ha}^{-1} \mathrm{C}$ ). All aboveground biomass and carbon estimates for T. superba stands were lower than for the estimates of young fast-growing plantations like Tectona grandis L. f., Eucalyptus spp. and Acacia spp. ( $\leq 30 \mathrm{y})$.
\end{abstract}

Résumé - Le potentiel des plantations de Terminalia superba Engl. \& Diels dans la production de bois et de biomasse (forêt de Mayombe, République Démocratique du Congo).

- Dans les années 1940-1950, de grandes plantations de limba (Terminalia superba Engl. \& Diels) on été mises en place en République Démocratique du Congo afin de réduire la pression sur les forêts naturelles.

- L'objectif de cette étude était d'évaluer le potentiel de ces plantations anciennes comme forêts de production de bois d'œuvre et puits de carbone.

- Cinq plantations différentes, âgées de 50 à 58 ans, ont été échantillonnées. Sur une surface de plus de 73 ha, le diamètre au-dessus des contreforts de 2680 arbres, la hauteur de fût de 265 arbres et la hauteur totale de 128 arbres ont été mesurés.

- Le volume commercial a été estimé à l'aide d'une régression du type loi de puissance $\left(R^{2}=0.95\right)$. Une fonction de variance du même type a été adoptée pour supprimer l'hétéroscedasticité des résidus. Le volume commercial a été estimé à $5.6 \pm 4.1 \mathrm{~m}^{3}$ par arbre et $183.9 \pm 135.0 \mathrm{~m}^{3} \mathrm{ha}^{-1}$. Ce dernier volume semble faible mais peut être expliqué par une chute de la densité d'arbres. Toutefois, l'accroissement moyen en volume $\left(3,2-3,7 \mathrm{~m}^{3} \mathrm{ha}^{-1} \mathrm{an}^{-1}\right)$ correspond bien avec des plantations de teck d'un âge comparable. Pour le limba, il y a une différence significative entre les valeurs d'estimation de biomasse et de quantité de carbone épigés dans cette étude (resp. 108,4 $\mathrm{Mg} \mathrm{ha}^{-1}$ et 54,2 $\mathrm{Mg} \mathrm{ha}^{-1}$ ) et dans les modèles existants (resp. 135,7-143,9 $\mathrm{Mg} \mathrm{ha}^{-1}$ et $67,9-72,0 \mathrm{Mg} \mathrm{ha}^{-1} \mathrm{C}$ ). Ces estimations de biomasse et de quantité de carbone épigés pour T. superba sont également inférieures à celles de jeunes plantations d'espèces à croissance rapide comme Tectona grandis L. f., Eucalyptus spp. and Acacia spp. ( $\leq 30$ ans).

\footnotetext{
* This study was performed at the two institutions but Ghent University is the main institution.

**Corresponding author: maaike.deridder@ugent.be
} 


\section{INTRODUCTION}

The Congo Basin is the second largest tropical forest in the world, second in extension only to Amazonia (FAO, 2005). Within this basin, the Democratic Republic of Congo (DRC) has the largest forest surface in continental Africa, covering 134 million hectares and including many different forest types (FAO, 2005). Still, deforestation and forest degradation in the tropics continue at an alarming rate. Between 1990 and 2000, $0.21 \%$ of the Central African forest disappeared annually and almost $0.15 \%$ was degraded every year (Duveiller et al., 2008).

Ecologically, sustainable forest management means that the management should not impair the ecological functions of the forest. This general concept, however, is quite difficult to achieve and to monitor and gives rise to controversy. Therefore the concept of sustained yield is being advocated as a more robust means to evaluate the non-detrimental character of timber logging and trade (Sands, 2005). Applying the principle of sustained yield implies that log removals should not exceed the capacity of the growing populations to replace them (annual growth = annual allowable cut). It is probably not the single unique condition (as other factors such as sociological and ecological parameters could also be taken into account), but the concept is generally accepted as a basic principle of forest management aiming at sustainability (Sands, 2005).

Tropical plantations seemed to play a minor role in the debate on sustainable management. However, when these plantations are created on degraded or agricultural land and carefully designed with respect to the local people, they can provide several environmental and socio-economic benefits (Evans and Turnbull, 2004). Lugo (1992) showed that the understory of older plantations can develop a high species richness with many native tree species. Thus, plantations can help in maintaining and restoring the diversity and productivity of forests after human-induced disruption. On the other hand, they can also provide a way to meet the national and international wood demand and to contribute to the country's economy (Marien and Mallet, 2004). According to the Forest Resources Assessment of 2005, forest plantations cover 140 million ha or $4 \%$ of the global forest area. About half of that area is located in the tropics and subtropics with no more than $10 \%$ in Africa (FAO, 2005).

Other arguments in favour of plantations are often found in the ongoing debate on climate change and global warming. Indeed, forests contain a large fraction of the terrestrial biomass, which underlines their importance as carbon sinks. The elemental composition of wood regarding the main components is relatively similar for all wood species, with carbon as the main component accounting for $50 \%$ of the woody biomass (Rowell, 2005). Kraenzel et al. (2003) measured a mean carbon content of $49.2 \%$ in teak. Elias and Potvin (2003) measured the carbon content of 32 neotropical species and found similar results although the wood carbon fraction may exhibit some small across species variations. Still, carbon content can be considered as half of the woody biomass. There is an increased interest to quantify this global carbon cycle under the clean development mechanism (CDM) of the Kyoto Protocol because it offers an interesting tool to finance sustainable forest management.

Volume and aboveground biomass (AGB) may be considered as the two main estimates within the framework of sustainable management and the mitigation of climate change. Measurements of both volume and AGB are difficult and time consuming (especially in tropical conditions), so often they are estimated from tree characteristics such as diameter or height, using allometric equations. The selection of the appropriate allometric model is a key element in the accurate estimation of volume and biomass (Navar, 2009). The requirements for these allometric equations are identical, so classical forest inventories provide all the necessary data (Brown, 1997). Still, allometric equations are a simplified way of estimating volume and biomass by taking measures of diameter and/or height. The actual measurements of volume and biomass (including carbon content) are more complex.

In tropical regions, most figures on volume, productivity and AGB are derived from natural forests (Brown, 1997; Chave et al., 2001; 2005) or younger plantations with exotic tree species (up to $30 \mathrm{y}$ ). In these short-rotation plantations, teak (Kraenzel et al., 2003; Ola-Adams, 1993), Eucalyptus spp. (Fonweban and Houllier, 1997; Forrester et al., 2004) and Acacia spp. (Bernhard-Reversat et al., 1993; Forrester et al., 2004) make up the majority of research projects. A few studies on AGB of short-rotation plantations with indigenous tree species like Terminalia superba Engl. and Diels (DRC and Nigeria) and Nauclea diderichii (De Wild.) Merr. (Nigeria) have also taken place (Ola-Adams, 1993; Onyekwelu, 2007; Pendje, 1993). However, these data were collected from other climate regions (Ola-Adams, 1993; Onyekwelu, 2007) or from small plots (<1 ha) (Pendje, 1993).

Terminalia superba Engl. \& Diels (trade name: limba) is a pioneer species, characterized by large buttresses and is typically found in secondary forests and fallows (Groulez and Wood, 1984; Humblet, 1946). Limba has a very large distribution area (from Sierra Leone to Angola) and is one of the major veneer timber species exported by African timber producers (Lamprecht, 1989). The peeled veneer is mainly used for plywood and furniture. Timber applications cover skirting boards, mouldings, framings and also doors. Limba is used especially for indoor applications because of its low resistance to fungi and insects (Groulez and Wood, 1984). In the 1930s, massive harvests of limba endangered the survival of this most abundant species throughout the Mayombe Forest, a natural forest covering parts of Gabon, the Republic of Congo, the DRC and Angola. Because of the natural presence of homogeneous stands, a straight stem, the ease of installing seedbeds and nursing seedlings and good natural pruning capacities, approximately 15000 ha of limba plantations were established around the Biosphere Reserve of Luki (Lower Congo Province, DRC) since the early 1940s (Humblet, 1946). Normally, half of the initial planting density was planned to be removed by thinnings but even without silvicultural treatments, most of the Congolese plantations of Terminalia superba could be considered as successful (Marien and Mallet, 2004). The combination of large-scale plantations in Central 
Africa with an indigenous tree species and an age of more than $50 \mathrm{y}$ offers a unique opportunity for research.

The objective of this study is to evaluate the potential of limba plantations around the Reserve of Luki in terms of wood and biomass production, including the sequestration of carbon. What is the ranking of limba among different indigenous and/or exotic plantation species, planted for timber production? And, can these plantations lower the pressure on the surrounding natural forests? Can limba play an important role as a carbon sink, compared to the other plantation species?

\section{MATERIAL AND METHODS}

\subsection{Study area}

The Mayombe Forest covers the most southern part of Gabon, the western parts of the Republic of Congo and the DRC, and Cabinda (Angola). The plantations of Terminalia superba are located at the southern border of the Mayombe Forest, within a drier semievergreen Guineo-Congolian rainforest (White, 1983) with large parts of secondary forests where former cultivation took place. In 1976, a relic of the Mayombe Forest in Luki -about $400 \mathrm{~km}$ coastward from Kinshasa- was assigned as a UNESCO Man and Biosphere Reserve. This reserve, located between $05^{\circ} 30^{\prime}$ to $05^{\circ} 45^{\prime} \mathrm{S}$ and $13^{\circ} 07^{\prime}$ to $13^{\circ} 15^{\prime} \mathrm{E}$, has a typical zonation pattern (Fig. 1): a strictly protected core area, a buffer zone with human settlements where conservation is emphasized and a surrounding transition area with the limba plantations where sustainable development is encouraged by several projects. The plantations were established 50 to 58 years ago following planting schemes with planting densities of 104 trees $\mathrm{ha}^{-1}(8 \times 12 \mathrm{~m})$. The total surface of the plantation area under study was 5952 ha. The exact age of each individual limba tree is mostly unknown but always included within the range of 50 to $58 \mathrm{y}$. Planting activities were not always executed on time and borders between different plantations are unclear.

A dry season of four to five months (May - October) and a short period with lesser rainfall (January - February) characterize the region. The proximity of the ocean, manifest by a strong nebulosity, buffers the intensity of this dry season. The mean yearly rainfall fluctuates between 1100 and $1400 \mathrm{~mm}$ (Humblet, 1946) but some particularly dry years exist. Temperatures oscillate around $26^{\circ} \mathrm{C}$ in the rainy season and drop to a minimum of $20{ }^{\circ} \mathrm{C}$ in the dry season. The altitude is between 500 and $600 \mathrm{~m}$ above sea level. Soils belong to the so-called system of the Mayombe, consisting of four layers with schists, quartzites, gneiss and sandstone. Within this system, the Luki Reserve is located on substrates of fertile and schists with graphite. Most soils are argillaceous with a porosity of 35 to $55 \%$, a $\mathrm{C} / \mathrm{N}$ ratio between 4 and 9 and $\mathrm{pH}$ between 4 and 6 . In general, soils are classified as humified Ferralsols with small local variations (Mukendi, 1973; Tutula, 1968).

\subsection{Inventory}

Within the homogeneous plantations in the Luki Reserve, strip sampling was chosen in five different plantations using a width of $48 \mathrm{~m}$ and a length varying from 250 to $1000 \mathrm{~m}$ (Fig. 2a). A minimal distance between two strips and plantation borders was respected.

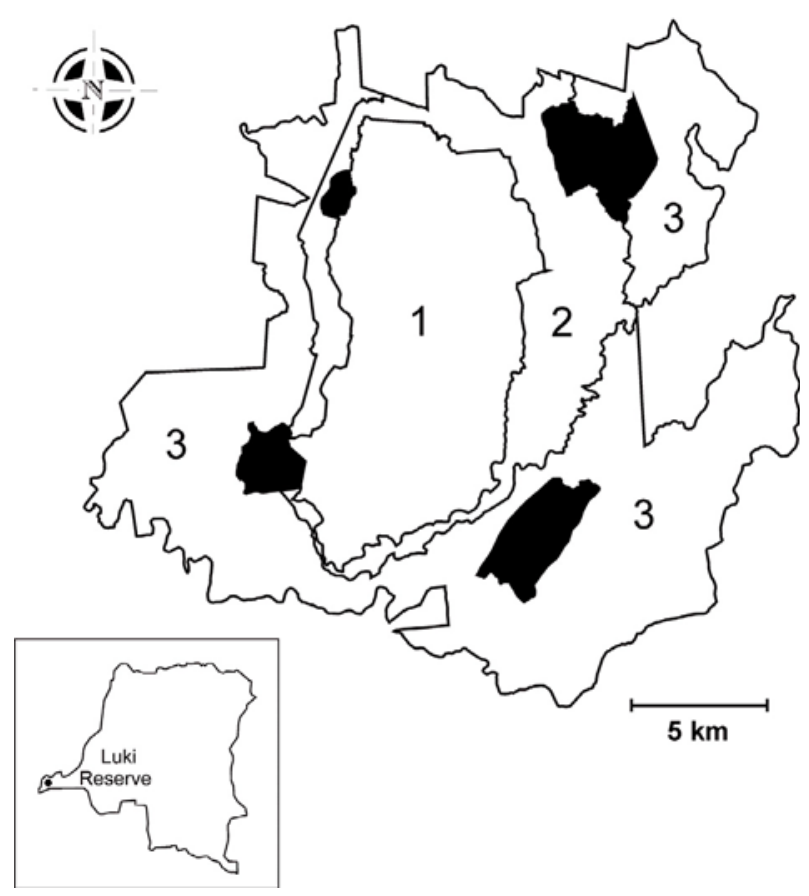

Figure 1. Location of the study area and division of the Luki Reserve (Lower Congo Province, DRC) in (1) a central zone, (2) a buffer zone, and (3) a transition zone with limba plantations. The black zones represents the four official enclaves within the Reserve. The presence of three of these enclaves in or near the plantations explains the human induced losses within the sample plots.

This way, the total inventory of 21 strips covered 73.3 ha, slightly more than $1 \%$ of the total surface of the limba plantations.

The circumference above buttresses of every limba tree was measured $(n=2680)$. Within this main sample, two subsamples were chosen: the buttress height of 2365 trees was noted while the bole height of 265 trees was measured. From this last subsample, 128 trees were selected to measure total tree height (Fig. 2b).

Measurements of circumference and buttress height were performed with a measuring tape in February and August-September 2007. Due to the fairly circular circumference of the stem, transformation to diameter above buttresses (DAB) is meaningful. During the dry season, when limba trees were mainly defoliated (April and August-September 2007), the bole height and total tree height were measured by using DAB classes of $10 \mathrm{~cm}$ as strata. All height measurements were performed with a Blume-Leiss hypsometer at a measuring distance of $30 \mathrm{~m}$.

\subsection{Felling trees}

Apart from the inventory, 18 trees were felled within the plantations. All felled trees were subject to repeated circumference measurements every $2 \mathrm{~m}$ until the first large branch. This way, the commercial volume was measured and form factors were calculated using the methods of Rondeux (1999). Form factors were calculated for every DAB class of $10 \mathrm{~cm}$. Trees larger than the largest DAB of the felled trees receive the same form factor as the largest felled tree. The diameter and length of large branches were also measured on a selection of eight of the felled trees. 


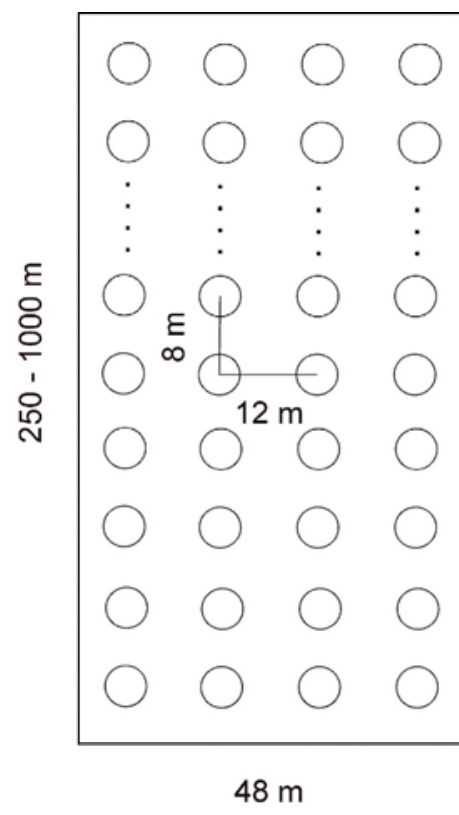

(a)

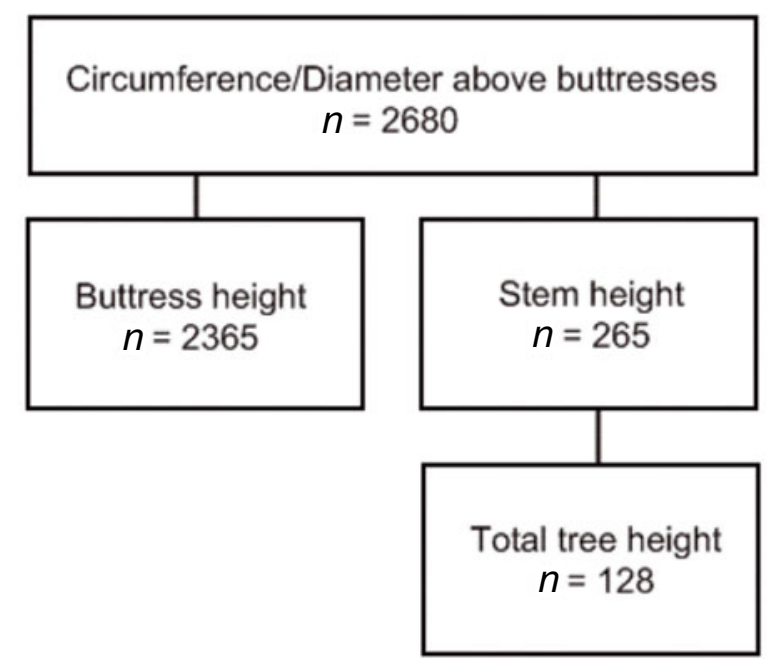

(b)

Figure 2. Sampling strategy. (a) Original planting distances were $8 \times 12 \mathrm{~m}(\mathrm{O}=$ tree). Sampling was done in strips of $48 \mathrm{~m}$ in width and 250 to $1000 \mathrm{~m}$ in length. The length is depending on the presence of roads, rivers, savannah or secondary forest areas, encountered during the inventory. (b) Schematic view on the number of samples for the different variables. Boxes with subsamples originate from larger samples and are connected by lines.

\subsection{Allometric relations for volume and aboveground biomass}

\subsubsection{A model for commercial volume}

In plantations, the most important volume is the commercial volume. The aim is to estimate this volume quickly and with a good accuracy. Measurements of the commercial volume were made on the 18 felled trees. Those 18 trees were also used to calculate the commercial volume with the classical volume equation:

$$
V=G H F
$$

where $V$ is the commercial volume $\left(\mathrm{m}^{3}\right), G$ the basal area above buttresses $\left(\mathrm{m}^{2}\right), H$ the bole height $(\mathrm{m})$ and $F$ the form factor. By means of statistical analysis (one way ANOVA), the measured and calculated commercial volume of these 18 trees were compared. If there were no significant differences, the calculated volume is in this particular study a good approximation of the volume measurement. In that case, the commercial volume was calculated with the classical Equation (1) based on 265 trees with a known DAB and bole height and a form factor derived from the 18 felled trees. The sample of 265 trees could then form the starting point for allometric equations. If differences were significant, the 18 felled and measured trees would be used.

Based on the adjusted determination coefficient $\left(R^{2}\right)$, the residual standard error (RSE), goodness-of-fit and distribution of residuals, one allometric equation was selected to estimate the commercial tree volume. All tested allometric equations, based on DAB only or DAB and bole height, were already successfully used under tropical conditions.

\subsubsection{Estimates of aboveground biomass using models and field data}

Direct measurement of the biomass and enclosed carbon were not possible due to an interdict on the exploitation of a representative sample of trees and the lack of adequate means to measure biomass (oven/weighing scales). Therefore, indirect methods were used. First, stem biomass was defined as the product of the estimated commercial stem volume and wood specific gravity. Specific gravity is defined as the oven-dry weight divided by the green volume and expressed in $\mathrm{g} \mathrm{cm}^{-3}$. For limba, a wood specific gravity of $0.55 \mathrm{~g} \mathrm{~cm}^{-3}$ is used (Groulez and Wood, 1984). Then, the product of the volume of the measured branches of eight felled trees and wood specific gravity was added. To calculate the volume of the branches, the classical formula (Eq. (1)) with a form factor of $1 / 3$, typical for cones, was used. Comparing the sum of stem biomass and biomass of the largest branches with data on AGB would lead to small underestimates because this study did not consider the biomass of twigs and leaves. According to Ola-Adams (1993) and Pendje (1993), small branches and leaves in limba plantations represent only $3 \%$ of the total AGB. This percentage was also added to the stem and branch biomass.

On the other hand, AGB models - based on destructive measurements - already exist. Unfortunately, most models on AGB are limited in use because of a small diameter range (diameter at breast height, DBH) and a limited number of sample trees. Moreover, they are often based on young plantations (Forrester et al., 2004; Kraenzel et al., 2003; Ola-Adams, 1993; Onyekwelu, 2007). Until now, no species-specific allometric equation for old limba plantations $(>40 \mathrm{y}$ ) exists. Therefore, the use of general models for the estimation of AGB in natural forests is accepted. Navar (2009) also stimulates the use of allometric equations for the estimation of biomass and carbon 


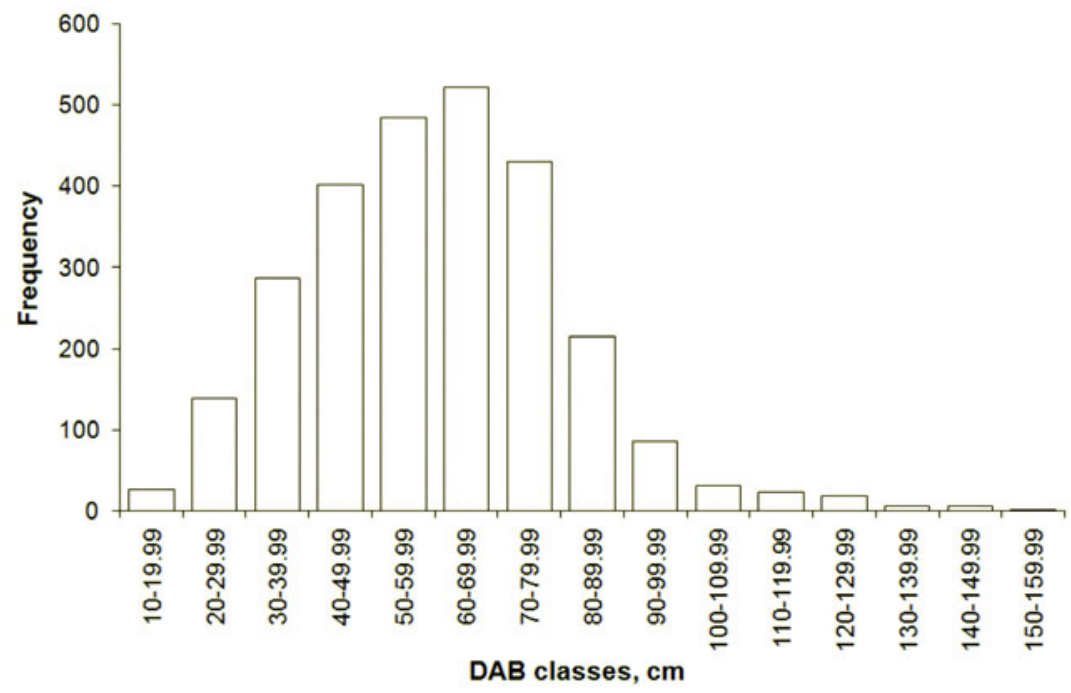

Figure 3. Distribution of the DAB of 2680 limba trees. The normal distribution, typical for even-aged plantations, is not found. The DAB class, containing the mean DAB of $60.3 \mathrm{~cm}$, is best represented throughout the sample area.

content. Both Brown (1997) and Chave et al. (2001; 2005) collected a broader data set and created models for dry to wet tropical forests. The model by Chave et al. (2005) is supposed to be consistent within the DBH range of 5 and $156 \mathrm{~cm}$ :

$\mathrm{AGB}=\rho \exp \left(-1.499+2.148 \ln (D)+0.207(\ln (D))^{2}-0.0281(\ln (D))^{3}\right)$

where AGB is the aboveground biomass $(\mathrm{kg}), D$ is the $\mathrm{DBH}(\mathrm{cm})$ and $\rho$ is the wood specific gravity $\left(\mathrm{g} \mathrm{cm}^{-3}\right)$. This model already includes the correction factor for the linearization of the AGB. Next to this rather complex model, three other widely used models, based on simple measurements of DBH were used.

$$
\begin{aligned}
& \mathrm{AGB}=42.69-12.8(D)+1.242\left(D^{2}\right) \\
& \mathrm{AGB}=\exp \{-2.134+2.530 \ln (D)\}
\end{aligned}
$$

both in moist forests (Brown, 1997),

$$
\ln (\mathrm{AGB})=-2.19+2.54 \ln (D)
$$

in regions with an annual rainfall below $3000 \mathrm{~mm} \mathrm{y}^{-1}$ (Chave et al., $2001)$. Because the present results are based on DAB $(\leq \mathrm{DBH})$, the AGB could be slightly underestimated, depending on the height of buttresses. However, this might be compensated by incorporating the biomass of these large buttresses.

The results of the used AGB models (Eqs. (2)-(5)) were compared with the sum of stem biomass, biomass of the largest branches and the percentage of biomass in twigs and leaves. Carbon is considered as half of the AGB estimates.

\subsection{Statistical analysis}

Data were analyzed with the statistical software packages SPSS ${ }^{\circledR}$ 16.0 (Analysis of Variance, Linear and Nonlinear Regression) and SPlus ${ }^{\circledR} 8.0$ (Generalized Nonlinear Least Squares Analysis with variance functions). The threshold probability level was 0.01 for determining significant differences and 0.001 for significant regressions.
During the analysis of variance, conditions of normality and homoscedasticity were tested. The selection of regressions was based on the determination coefficient, goodness-of-fit, the distribution of residuals and the residual standard error.

\section{RESULTS}

\subsection{Actual structure of the plantations}

The actual mean density is 33 stems $^{-1}$ which means that almost $70 \%$ of the original stand has disappeared due to natural dieback and illegal cuttings. The variation in DAB is very high $(11-155 \mathrm{~cm})$ and the distribution of DAB is not normal $(p<0.001$, Fig. 3). The mean DAB of $60.3 \pm 20.7 \mathrm{~cm}$ (standard deviation) coincides with the originally proposed minimum felling diameter (MFD) (Humblet, 1946). Exactly 50\% of the trees reached this MFD. The basal area (BA) of barely $10.5 \pm 7.4 \mathrm{~m}^{2} \mathrm{ha}^{-1}$ also illustrates the decrease in density.

The mean height of the buttresses was $202.5 \pm 69.2 \mathrm{~cm}$. Almost $72 \%$ of all measured individuals had buttresses higher than breast height. There exists a clear relation between the height of the buttresses and DAB. The larger the trees, the higher the buttresses (Fig. 4):

$$
H_{\text {buttress }}=96.16 \mathrm{e}^{0.012 D A B}\left(\text { Adjusted } R^{2}=0.46, p<0.001\right)
$$

where $H_{\text {buttress }}$ is the height of buttresses $(\mathrm{cm})$.

The mean bole height of 265 trees is $25.2 \pm 6.4 \mathrm{~m}$ while the mean total tree height of 128 trees is $31.5 \pm 6.7 \mathrm{~m}$. Looking at the heights cited by Groulez and Wood (1984), the plantations can be considered mature, i.e. reaching exploitable dimensions. The mean ratio between bole and total tree height of 128 trees is 0.78 , indicating that almost $80 \%$ of the trunk has a commercial value. 


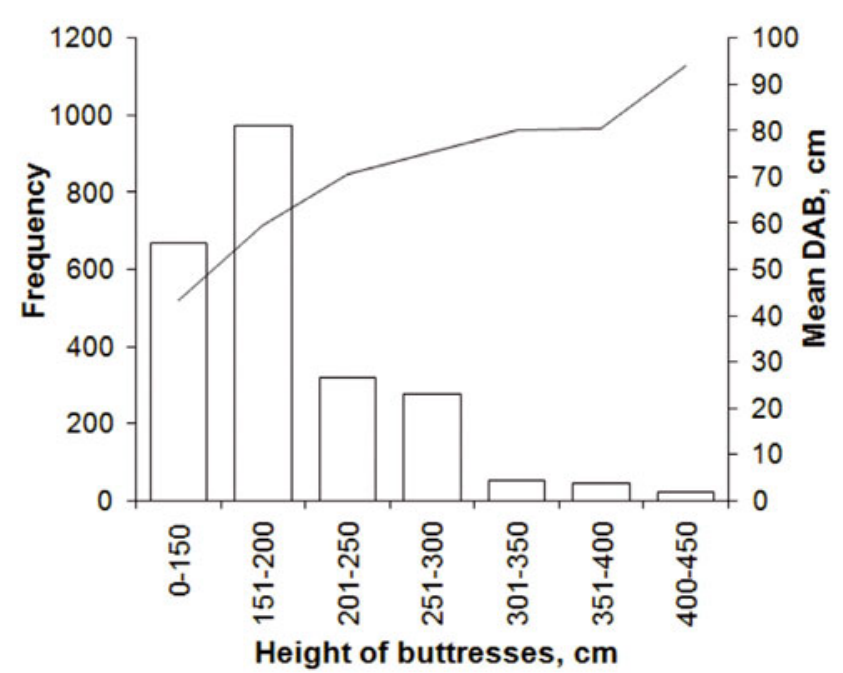

Figure 4. The relation between the height of the buttresses, the frequencies of trees within classes of buttress height and the mean DAB within those classes $(n=2365)$. Buttress height increases significantly with DAB.

The DAB-height curves were constructed for bole height ( $n=265$ trees) and total tree height $(n=128$ trees). A selection of four robust models gave the best results: logarithmic, quadratic, inverse and linearized power law regressions. All regressions are significant $(p<0.001)$ and show comparable adjusted determination coefficients $\left(R^{2}\right)$ for the estimate of bole height (0.35-0.39). Based on the goodness-of-fit, logarithmic and power law relations revealed quite similar results but a slightly better distribution of the residuals supports the decision to choose the logarithmic regression (Fig. 5).

\subsection{Commercial volume}

No significant differences were found between the 18 measured and computed volumes with Equation (1). In addition, the data set of 265 trees with measured heights and DAB covers the whole range of DAB $(11-155 \mathrm{~cm})$ while the 18 felled trees only cover a range of DAB from 18 to $91 \mathrm{~cm}$. Therefore, all tested models are based on 265 trees of which the commercial volume was calculated by Equation (1). The mean form factor is 0.68 .

Inserting height in volume models only made them more complex and did not add any significant value to the performance of the model ( $R^{2}$, RSE, goodness-of-fit, residuals). From the used linear, quadratic, cubic and (nonlinear and log$\log$ transformed) power law equations, the most robust simple models all have a $R^{2} \geq 0.90$. More complex cubic equations did not result in significant differences in $R^{2}$, RSE, goodnessof-fit or distribution of residuals and were therefore abandoned for further analysis. Notwithstanding the widely used log-log regression, Tausch and Tueller (1988) found that this type of regression is less precise and accurate than nonlinear regression. This study also contributes towards the establishment of

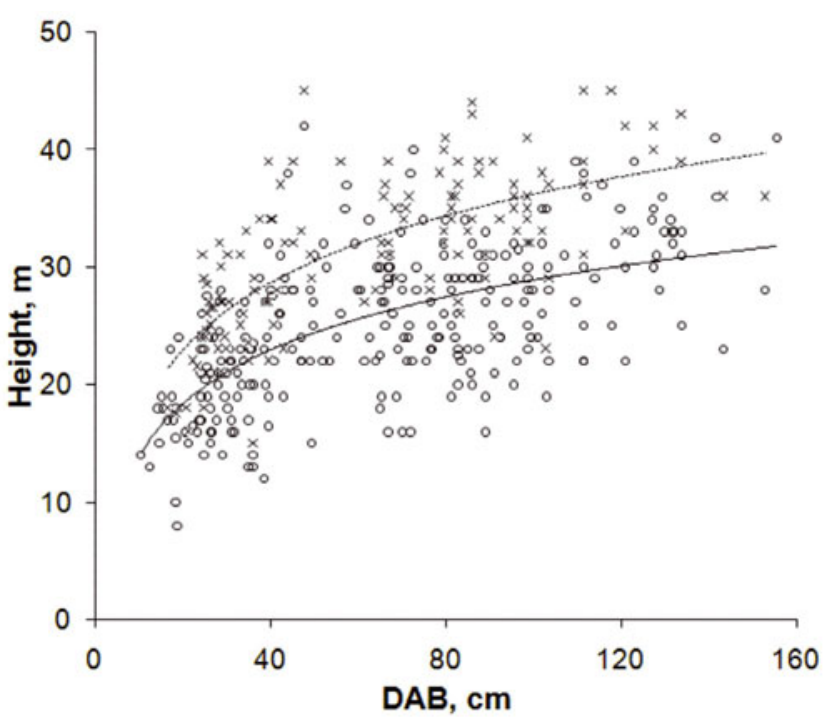

Figure 5. DAB-height curves for stem and total tree height (plain line: bole height $=-1.08+6.51 \ln (\mathrm{DAB}), R^{2}=0.38, p<0.01$ and dotted line: total tree height $=-1.64+8.22 \ln (\mathrm{DAB}), R^{2}=0.49$, $p<0.01)$. Dots and crosses respectively represent measurements of bole and total tree height.

nonlinear regressions, selecting a nonlinear power law model as the most appropriate for the commercial volume estimates of limba trees within a DAB range from 11 to $155 \mathrm{~cm}$ (Tab. I):

$$
V=3.24 \times 10^{-4} D A B^{2.35} \quad(p<0.001) .
$$

This model uses a variance function that counters the heteroscedastic character of the residual plot:

$$
\operatorname{var}\left(V_{i}\right)=\left|V_{i}\right|^{1.83}
$$

with $\operatorname{var}\left(V_{i}\right)$ the variance of the estimated commercial volume of the $i$ th sample tree.

In addition, the use of this variance function leads to a better value for log-likelihood and RSE and smaller standard deviations of the coefficients of the model (Tab. I and Fig. 6).

This model (Eq. (7)) was used to estimate the volume of the rest of the main sample $(n=2415)$. The estimated mean commercial volume was $5.6 \pm 4.1 \mathrm{~m}^{3}$ per tree. Multiplied by the actual stand density, this results in a commercial stand volume of $183.9 \pm 135.0 \mathrm{~m}^{3} \mathrm{ha}^{-1}$. Multiplied by the planned density $\left(52\right.$ trees $\mathrm{ha}^{-1}$ ) or even the initial planting density (104 trees ha ${ }^{-1}$ ), leads to values of respectively 290.3 and $580.7 \mathrm{~m}^{3} \mathrm{ha}^{-1}$ (Tab. II). "Planned density" is the final density that former foresters had proposed at the end of the rotation, after one thinning operation. The case of potential stand volume with the initial planting density is more doubtful since limba would not have achieved the same growth if the initial planting density would have remained unchanged.

\subsection{Aboveground biomass}

The use of existing models results in AGB estimates between 135.7 and $143.9 \mathrm{Mg} \mathrm{ha}^{-1}$ (or 4.1 to $4.4 \mathrm{Mg}$ per tree) 
Table I. Statistical characteristics of the nonlinear power law model (Eq. (7)). SD = standard deviation, CI = confidence interval $(95 \%)$, LLV $=$ log-likelihood value, $p<0.001$ (with and without variance function, Eq. (8)).

\begin{tabular}{|c|c|c|c|c|c|c|c|c|c|c|c|}
\hline & $a$ & $b$ & $\mathrm{SD}(a)$ & $\mathrm{SD}(b)$ & $\mathrm{CI}$ & & $\mathrm{CI}$ & & LLV & RSE & Adj. $R^{2}$ \\
\hline Without variance function & $1.96 \times 10^{-4}$ & 2.458 & $4.42 \times 10^{-5}$ & 0.047 & $1.09 \times 10^{-4}$ & $2.83 \times 10^{-4}$ & 2.365 & 2.552 & -583.944 & 2.220 & 0.95 \\
\hline
\end{tabular}

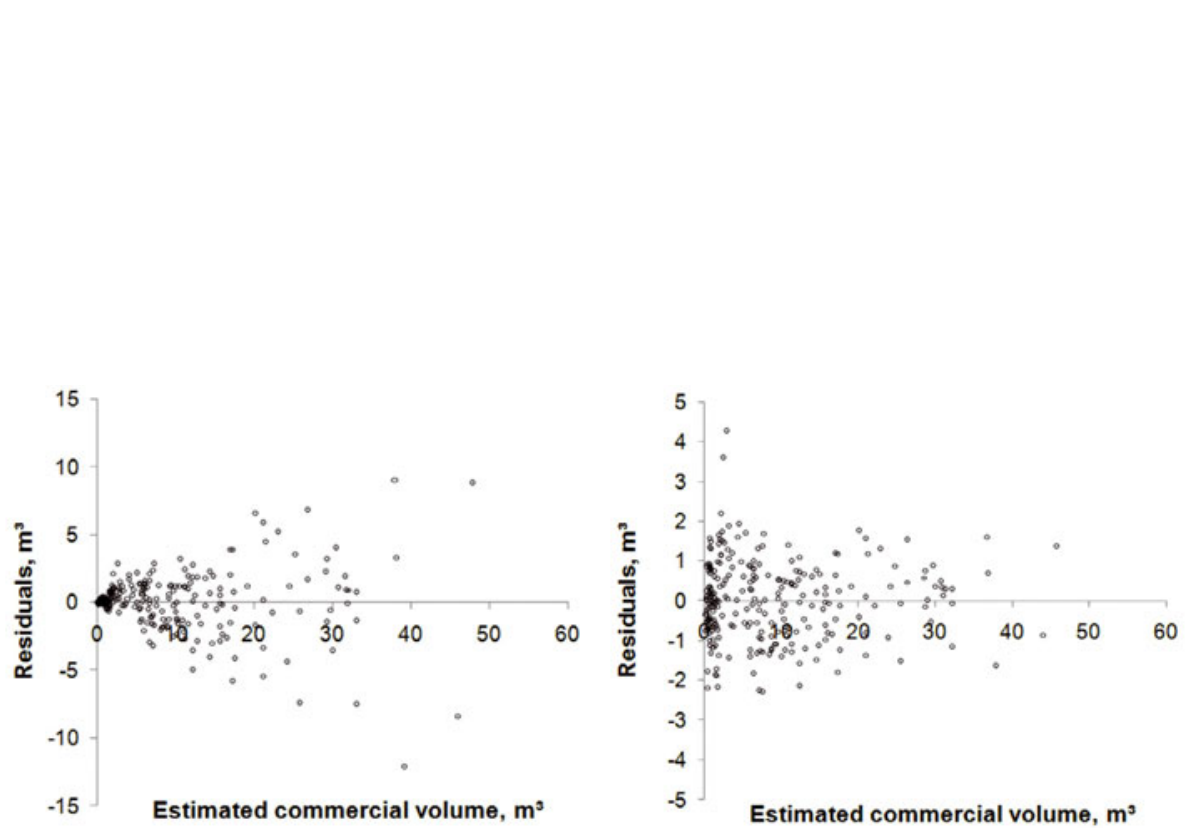

(a)

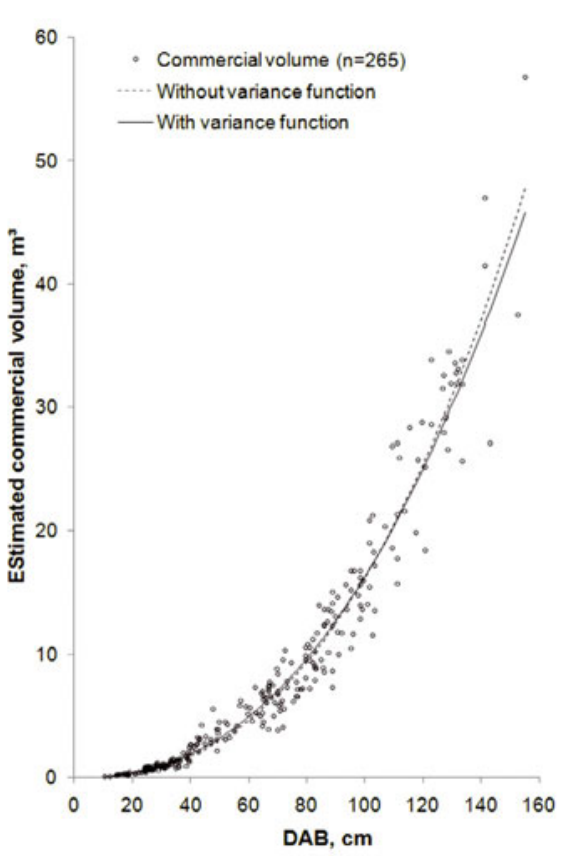

(c)

Figure 6. Residual plot of the power law regression (a) before, and (b) after applying the variance function (Eq. (8)), and (c) goodness-of-fit of both power law regressions. It is clear that the use of a power law variance function counters the heteroscedasticity of the residual plot.

Table II. Volume estimates of limba plantations, using the power law regression (Eq. (7)) (age between 50 and $58 \mathrm{y}$ ).

\begin{tabular}{lc}
\hline Mean commercial volume $\left(\mathrm{m}^{3}\right.$ per tree $)$ & $5.6 \pm 4.1$ \\
Mean stand volume $\left(\mathrm{m}^{3} \mathrm{ha}^{-1}\right)$ & $183.9 \pm 135.0$ \\
Minimum annual increment $\left(\mathrm{m}^{3} \mathrm{ha}^{-1} \mathrm{y}^{-1}\right)^{*}$ & $3.2 \pm 2.3$ \\
Maximum annual increment $\left(\mathrm{m}^{3} \mathrm{ha}^{-1} \mathrm{y}^{-1}\right)^{* *}$ & $3.7 \pm 2.7$ \\
Mean planned stand volume $\left(\mathrm{m}^{3} \mathrm{ha}^{-1}\right)$ & $290.3 \pm 213.2$ \\
Minimum annual increment $\left(\mathrm{m}^{3} \mathrm{ha}^{-1} \mathrm{y}^{-1}\right)^{*}$ & $5.0 \pm 3.7$ \\
Maximum annual increment $\left(\mathrm{m}^{3} \mathrm{ha}^{-1} \mathrm{y}^{-1}\right)^{* *}$ & $5.8 \pm 4.3$ \\
Mean potential stand volume $\left(\mathrm{m}^{3} \mathrm{ha}^{-1}\right)$ & $580.7 \pm 426.4$ \\
Minimum annual increment $\left(\mathrm{m}^{3} \mathrm{ha}^{-1} \mathrm{y}^{-1}\right)^{*}$ & $10.0 \pm 7.4$ \\
Maximum annual increment $\left(\mathrm{m}^{3} \mathrm{ha}^{-1} \mathrm{y}^{-1}\right)^{* *}$ & $11.6 \pm 8.5$ \\
\hline
\end{tabular}

${ }^{*}$ Mean annual growth if the plantations were 58 years old.

${ }^{* *}$ Mean annual growth if the plantations were 50 years old.

(Tab. III). This corresponds with carbon content estimates between 67.9 and $72.0 \mathrm{Mg} \mathrm{ha}^{-1}$ (or 2.1 to $2.2 \mathrm{Mg}$ per tree). Variances were not equal so the Tamhane's test was used to reveal significant differences between the models. Although the difference in AGB estimates is significant for equations (3) and (4) (Brown, 1997), the difference between the lowest and highest estimates of AGB is only 6\%. Both models of Chave et al.
(2001; 2005) result in very comparable estimates, situated between the two models of Brown (1997).

The mean stem biomass was $3.1 \mathrm{Mg}$ per tree or 101.1 $\mathrm{Mg} \mathrm{ha}^{-1}$. The portion of volume and biomass from large branches of 8 measured crowns is very small (4.2\%). The portion of twigs and leaves is quite constant throughout time and a fraction of 3.0\% is added (Ola-Adams, 1993; Pendje, 1993). Considering the sum of the mean stem biomass, the biomass portion of the measured large branches ( 8 trees) and the portion of leaves and twigs (Ola-Adams, 1993; Pendje, 1993), the AGB would be $3.3 \mathrm{Mg}$ per tree or $108.4 \mathrm{Mg} \mathrm{ha}^{-1}$ (or $1.7 \mathrm{Mg} \mathrm{C}$ per tree and $\left.52.4 \mathrm{Mg} \mathrm{C} \mathrm{ha}^{-1}\right)$. This is significantly lower than the estimates produced by equations (2)-(5).

\section{DISCUSSION}

\subsection{Past and present structure of the plantations}

It is clear that the initial density of 104 stems ha $^{-1}$ has declined heavily due to human pressure and natural dieback. An exponential decrease in density did not only occur during the last three decades (unpubl. data). Tutula (1968) and Mukendi (1973) already noted a large decrease in density, ranging from 
Table III. Estimates of the above-ground biomass of limba plantations by using field data and existing models (age $=50-58$ y).

\begin{tabular}{|c|c|c|c|c|c|}
\hline & $\begin{array}{c}\text { Stem biomass + large branches } \\
+ \text { twigs and leaves* }\end{array}$ & Equation (2) & Equation (3) & Equation (4) & Equation (5) \\
\hline Mean stand AGB $\left(\mathrm{Mg} \mathrm{ha}^{-1}\right)$ & $108.4 \pm 79.6$ & $141.5 \pm 104.3$ & $135.7 \pm 90.7$ & $143.9 \pm 114.8$ & $142.0 \pm 113.8$ \\
\hline Maximum annual increment $\left(\mathrm{Mg} \mathrm{ha}^{-1} \mathrm{y}^{-1}\right)^{* * *}$ & $2.2 \pm 1.6$ & $2.8 \pm 2.1$ & $2.7 \pm 1.8$ & $2.9 \pm 2.3$ & $2.8 \pm 2.3$ \\
\hline Mean planned stand AGB $\left(\mathrm{Mg} \mathrm{ha}^{-1}\right)$ & $171.2 \pm 125.7$ & $223.5 \pm 164.7$ & $214.3 \pm 143.2$ & $227.2 \pm 181.3$ & $224.1 \pm 179.7$ \\
\hline Minimum annual increment $\left(\mathrm{Mg} \mathrm{ha}^{-1} \mathrm{y}^{-1}\right)^{* *}$ & $3.0 \pm 2.2$ & $3.9 \pm 2.8$ & $3.7 \pm 2.5$ & $3.9 \pm 3.1$ & $3.9 \pm 3.1$ \\
\hline Maximum annual increment $\left(\mathrm{Mg} \mathrm{ha}^{-1} \mathrm{y}^{-1}\right)^{* * *}$ & $3.4 \pm 2.5$ & $4.4 \pm 3.3$ & $4.3 \pm 2.9$ & $4.5 \pm 3.6$ & $4.5 \pm 3.6$ \\
\hline Mean potential stand AGB $\left(\mathrm{Mg} \mathrm{ha}^{-1}\right)$ & $342.4 \pm 251.4$ & $446.9 \pm 329.4$ & $428.5 \pm 286.4$ & $454.3 \pm 362.6$ & $448.3 \pm 359.4$ \\
\hline Minimum annual increment $\left(\mathrm{Mg} \mathrm{ha}^{-1} \mathrm{y}^{-1}\right)^{* *}$ & $5.9 \pm 4.3$ & $7.7 \pm 5.7$ & $7.4 \pm 4.9$ & $7.8 \pm 6.3$ & $7.7 \pm 6.2$ \\
\hline Maximum annual increment $\left(\mathrm{Mg} \mathrm{ha}^{-1} \mathrm{y}^{-1}\right)^{* * *}$ & $6.9 \pm 5.0$ & $8.9 \pm 6.6$ & $8.6 \pm 5.7$ & $9.1 \pm 7.3$ & $9.0 \pm 7.2$ \\
\hline
\end{tabular}

${ }^{*}$ Data for twigs and leaves originates from Ola-Adams (1993) and Pendje (1993).

${ }^{* *}$ Mean annual growth if the plantations were 58 years old.

*** Mean annual growth if the plantations were 50 years old.

20 to $54 \%$, depending on the location of the sample plot. As the first losses in density can be assigned to the inferior quality of planting material or problems on steep slopes, the main cause during the last decades is the increasing population pressure in the Lower Congo Province, also increasing the need for fuelwood and the production of charcoal (Nsenga, pers. comm., 2007). In 2007, many charcoal furnaces, together with illegally cut limba trees for timber use were observed during the field sampling campaigns. Combined with the establishment of large agricultural areas for manioc (Manihot esculenta L.) and rice (varieties of Oryza glabberima Steudel and Oryza sativa L.), the pressure on the natural forests and the limba plantations is extremely high.

After 50 to $58 \mathrm{y}$, the mean DAB of $60 \mathrm{~cm}$ corresponds with the planned MFD (Humblet, 1946). The 23-year old limba plantations already reached a DAB of approximately $37 \mathrm{~cm}$, confirming the fast-growing character of this tree species (Mukendi, 1973). While even-aged plantations are known for their normal diameter distribution, that distribution has become a normal curve with a right-hand tail, representing a few larger trees. Several causes could explain the large variation in DAB: presence of large, old natural limba trees (already present at time of initiating the plantations, cf. maximum DAB $155 \mathrm{~cm})$, natural regeneration or small scale replanting with small understory trees (lack of light) (cf. minimum DAB of $10 \mathrm{~cm}$ ), grouping of sample plots of slightly different ages (50-58 y) and different soil characteristics (amount of organic material, carbon, nitrogen, $\mathrm{pH}$ and soil texture). Sarlin (1963) found a correlation between tree growth and soil characteristics such as exchangeable bases and $\mathrm{pH}$. However, this correlation is stronger in young plantations as older trees modify the soil, enriching it with some of the elements contained in its leaves, this process being in proportion to its rate of growth (Sarlin, 1963). Finally, uncontrolled cuttings result in uneven competition, also contributing to the asymmetry of the diameter distribution.

A recent inventory (Maloti, 2009, unpubl. data) of 29 ha within the core area of the Luki Reserve (natural primary and secondary forest) lead to a basal area of $21.6 \mathrm{~m}^{2} \mathrm{ha}^{-1}$ (di- ameter trees $\geq 15 \mathrm{~cm}$ ), twice the value of the current basal area in the plantations $\left(10.5 \mathrm{~m}^{2} \mathrm{ha}^{-1}\right)$. Of course, this inventory occurred in a natural forest with a vertical stratification (even without measuring the smallest diameters) while plantations are mostly characterized by one tree layer (with no or little understory growth) and fixed planting distances. The potential basal area of the limba plantations $\left(33.1 \mathrm{~m}^{2} \mathrm{ha}^{-1}\right.$ with 104 trees ha ${ }^{-1}$ ) however is higher but it is not known if this potential basal area would have been reached when 104 trees were still present as a result of intraspecific competition.

One of the main characteristics of limba is the presence of large buttresses. As trees grow taller, their crowns get exposed to the stronger winds in the upper canopy layer, resulting in larger buttresses to assure mechanical stability. The significant correlation between $\mathrm{DAB}$ and the height of buttresses also occurs in other tree species (Woodcock et al., 2000). While Woodcock et al. (2000) fitted a second-order polynomial with an upper limit around $450 \mathrm{~cm}$, the exponential regression model based on DAB and buttress height of limba trees does not impose an upper limit. The largest limba tree in this inventory had a DAB of $155 \mathrm{~cm}$ and can be considered as rare (only 2 trees with DAB $>150 \mathrm{~cm}$ ). The calculated upper height of buttresses is $580 \mathrm{~cm}$, an estimate that still corresponds with the inventory results. The type of regression can be considered as species-specific.

The maximum total tree heights of 40 to $50 \mathrm{~m}$, found in natural forests (Groulez and Wood, 1984), are met in $9 \%$ of the total tree height measurements so planted limba trees can reach heights comparable to those of natural trees. Groulez and Wood (1984) and Lamprecht (1989) mention normal heights for adult trees of $30 \mathrm{~m}$ thus the studied plantations can be considered as mature and appropriate for exploitation. For commercial purposes, bole height and ratio between bole height and total tree height are more important. Bole heights varying from 20 to $25 \mathrm{~m}$ are considered as high and found in mature forests as well as the plantations under study (Groulez and Wood, 1984). Tutula (1968) measured heights in 14- to 18 -year old plantations, resulting in portions of 72 to $79 \%$ branch-free tree height. The corresponding bole heights were 
17 to $\left.21 \mathrm{~m} \mathrm{(0.8} \mathrm{to} 1.2 \mathrm{~m} \mathrm{y}^{-1}\right)$, once more confirming the pioneer character of the species, i.e. fast growth during the first years. The current value of $78 \%$ indicates that the portion of bole height remains constant after the first $20 \mathrm{y}$ and corresponds with the values of Groulez and Wood (1984), namely between 0.7 and 0.8 . Notwithstanding the wide planting distances, this species has an excellent natural pruning capacity and a high percentage of valuable stem timber. Compared to teak (Tectona grandis L. f.), where only a $60 \%$ ratio was obtained after an intensive pruning program (Víquez and Pérez, 2005), the management of limba plantations might be less labour-intensive and costly.

Furthermore, the DAB-height curve of natural uneven-aged forest has a typical point of inflection (Rondeux, 1999). Although the plantations are not perfectly even-aged (50-58 y), the DAB-height curve has the classic shape of even-aged forests, without a point of inflection.

\subsection{Commercial volume}

In tropical regions, the determination of form factors is not obvious and therefore, little information is available, leading to significant overestimates in volume and biomass. Very often, limba is described as a tree species with a cylindrical stem (e.g. Humblet, 1946). However, Mabela (1978) suggested a form factor of 0.7 for limba, very close to the mean measured value of 0.68 .

The objectives at the time of initializing the plantations differ considerably depending on the author. Humblet (1946) estimated the mean total tree volume of a mature tree at $6 \mathrm{~m}^{3}$. Limba trees would reach maturity around 50-60 y in plantations where half of the original density was cut by thinning interventions, leaving 52 trees $\mathrm{ha}^{-1}$ for the final exploitation (Humblet, 1946). Tutula (1968) and Lamprecht (1989) estimated the total volume without defects not less than $200 \mathrm{~m}^{3} \mathrm{ha}^{-1}$. Groulez and Wood (1984) predict rotation periods of $40 \mathrm{y}$ in the most favourable conditions and $65 \mathrm{y}$ in less favourable conditions. In general, a final density around 52 trees ha ${ }^{-1}$ with a total tree volume around $6 \mathrm{~m}^{3}$ is assumed after $50-60 \mathrm{y}$. The expected total stand volume would fluctuate around $300 \mathrm{~m}^{3} \mathrm{ha}^{-1}$, hence the estimated commercial volume would be about $230 \mathrm{~m}^{3} \mathrm{ha}^{-1}$.

Today, the mean DAB of $60 \mathrm{~cm}$ coincides with the MFD at an age between 50 and $58 \mathrm{y}$, obtaining the expected values without the support of the scheduled management interventions. The actual mean commercial volume easily passes $5 \mathrm{~m}^{3}$ per tree so the mean total tree volume will also reach the proposed $6 \mathrm{~m}^{3}$ per tree, taking into account the bole/tree height ratio of 0.78 .

Most likely, the commercial volume per tree was not heavily influenced by recent density losses, i.e. after the first $30 \mathrm{y}$ following the installation. Within that period, limba has terminated its main growth period and the largest losses in plant density took place. Cutting trees after $30 \mathrm{y}$ will not have a major impact since growth already culminated (pioneer species). In addition, the canopy closure is incomplete so multiplying the individual volume with the actual $(n=33)$ or the planned density $(n=52)$, can only create small or no overestimates of the initially planned volume. Thus, the estimated planned commercial volume $\left(290 \mathrm{~m}^{3} \mathrm{ha}^{-1}\right)$ could be larger than the proposed commercial volume of $230 \mathrm{~m}^{3} \mathrm{ha}^{-1}$ (Tab. II).

In reality, illegal harvesting and natural die-off even surpassed the number of trees that would have been cut by thinning operations, so that the present volume of the plantations is lower than the proposed commercial volume. At the tree level, all expectations were fulfilled. Where management seemed to have no major impact on the accomplishment of the MFD, thinning operations are recommended to obtain the proposed commercial volume. The hypotheses of Humblet (1946) and Tutula (1968) proved to be very accurate but did not entirely succeed at the stand level without a minimum of forest management.

One of the main reasons in the 1950s to install plantations, was the low density of exploitable trees, only $15-35 \mathrm{~m}^{3} \mathrm{ha}^{-1}$ in natural forests (Humblet, 1946; Tutula, 1968). The present mature plantations with commercial volumes of $184 \mathrm{~m}^{3} \mathrm{ha}^{-1}$ offer an alternative that can lower the pressure on natural forests by providing enough exploitable trees.

When comparing volume estimates with other plantations and natural forests, one should always keep in mind forest characteristics that determine the volume: age, soil, climate, elevation, purpose and presence of management. Table IV lists volume estimates for other limba plantations, plantations with other African indigenous species, hardwood plantations (teak), pulp and fuelwood plantations (Eucalyptus and Acacia spp.) with exotic species and natural secondary forests. Primary forest is not neighbouring the plantations but the presence of secondary forest in plantation gaps allows comparing with secondary forests and woodlands. While middle-aged limba plantations in the Republic of Congo have lower or similar volumes (Marien and Mallet, 2004), younger plantations in Ivory Coast have exceptional high growth values (Dupuy et al., 1999). Management interventions, together with other climate and soil conditions, explain the success of these plantations. Framiré (Terminalia ivorensis A. Cheval) and obeché (Triplochiton scleroxylon K. Schum.) plantations also produce more volume at a younger age in West Africa (Dupuy et al., 1999) while the production of okoumé is inferior to the limba plantations (Marien and Mallet, 2004).

Teak (Tectona grandis L. f.) is a widely planted species, known for its durable timber. Although the applications of limba and teak differ considerably, they both are hardwood species, found in plantations with a rather long rotation period (40 to $60 \mathrm{y}$ ). In Ivory Coast, the situation of teak plantations is highly comparable to limba (Dupuy et al., 1999). The volume production of the limba plantations also falls within the range of volume production of teak plantations in India, keeping in mind that the total volume production is higher than the commercial volume production (Beghagel and Monteuuis, 1999; Evans and Turnbull, 2004). Unfortunately, no or little information is available on planting densities.

Species for the production of pulp or fuelwood should grow very fast but criteria like merchantable height, straightness of stem or presence of defects are less important. Enormous densities are planted to obtain a large stand volume with very high 
Table IV. Commercial volume estimates in tropical plantations and natural forests (List of other studies on volume by several authors, with indigenous and exotic species and important influences like density and age. Comparison with the current results is based on this table).

\begin{tabular}{|c|c|c|c|c|c|c|c|}
\hline Forest type & Country & $\begin{array}{c}\text { Density } \\
\left(\mathrm{ha}^{-1}\right)\end{array}$ & $\begin{array}{l}\text { Age } \\
(\mathrm{y})\end{array}$ & $\begin{array}{c}\text { Tree volume } \\
\left(\mathrm{m}^{3}\right)\end{array}$ & $\begin{array}{c}\text { Stand volume } \\
\left(\mathrm{m}^{3} \mathrm{ha}^{-1}\right)\end{array}$ & $\begin{array}{c}\text { Volume increment } \\
\left(\mathrm{m}^{3} \mathrm{y}^{-1} \mathrm{ha}^{-1}\right)\end{array}$ & Author \\
\hline Limba plantation & Rep. of Congo & - & $35-40$ & - & 180.0 & $4.0-4.5$ & Marien and Mallet (2004) \\
\hline Limba plantation & Rep. of Congo & 72 & 41 & 1.8 & 130.1 & 3.2 & Groulez and Wood (1984) \\
\hline Limba plantation & Ivory Coast & - & 20 & - & 240.0 & 12.0 & Dupuy et al. (1999) \\
\hline Terminalia ivorensis plantation & Ivory Coast & - & 32 & - & 192.0 & 6.0 & Dupuy et al. (1999) \\
\hline Aucoumea klaineana plantations & Gabon & - & $15-51$ & - & - & 2.0 & Marien and Mallet (2004) \\
\hline Triplochiton scleroxylon plantation & Ivory Coast & - & 24 & - & 264.0 & 11.0 & Dupuy et al. (1999) \\
\hline Teak plantation & Ivory Coast & - & 68 & - & 231.2 & 3.4 & Dupuy et al. (1999) \\
\hline Teak plantation* & India & - & $60-80$ & - & $240.0-640.0$ & $4.0-8.0$ & Evans and Turnbull (2004) \\
\hline Teak plantation* & India & - & $40-60$ & - & $40.0-360.0$ & $1.0-6.0$ & Beghagel and Monteuuis (1999) \\
\hline Eucalyptus globulus plantation* & Australia & 1515 & 11 & $<0.1$ & 71.3 & 6.5 & Forrester et al. (2004) \\
\hline Eucalyptus saligna plantations* & Cameroon & Ca. 1000 & $11-19$ & Ca. $0.2-1.0$ & $154.5-980.5$ & $14.1-51.6$ & Fonweban and Houllier (1997) \\
\hline \multirow[t]{3}{*}{ Pinus caribaea plantation } & Australia & 2204 & 9.3 & 0.1 & 145.1 & 15.6 & Evans and Turnbull (2004) \\
\hline & & 1680 & 9.3 & 0.1 & 130.9 & 14.7 & \\
\hline & & 747 & 9.3 & 0.1 & 103.2 & 11.1 & \\
\hline Acacia mearnsii plantation* & Australia & 1515 & 11 & $<0.1$ & 76.3 & 6.9 & Forrester et al. (2004) \\
\hline
\end{tabular}

${ }^{*}$ Total instead of commercial volume.

volume increments in a short period of time. Considering the different purposes of these plantations, comparison should be made with caution.

The estimated potential volume increments do not seem reliable (10-12 $\left.\mathrm{m}^{3} \mathrm{ha}^{-1} \mathrm{y}^{-1}\right)$. Those increments would be almost equal to fast-growing Acacia and Eucalyptus spp., while the planting densities of limba trees are only an insignificant fraction of those planted for pulp or fuelwood purposes. Ignoring the large density losses on DAB and volume growth completely, results in potential volume increments that overestimate the real potential of the plantation.

\subsection{Aboveground biomass}

Compared to other species, limba has a very low portion of crown biomass (large branches, twigs and leaves). For 30 y old Nauclea didderichii plantations, the crown biomass accounts for $16 \%$ (Onyekwelu, 2007). The crown biomass of teak plantations varies from 18 to $25 \%$ (Kraenzel et al., 2003).

Pendje (1993) measured a crown biomass of $19 \%$ in the 35 years old limba plantations of Luki. The older the plantations, the smaller the crown portion as a result of good natural pruning capacities. Ola-Adams (1993) estimates the crown biomass around $3 \%$ in very dense and $7 \%$ in the less dense Nigerian stands of limba. The larger the planting distances, the higher the portion of crown biomass (power law regression based on Ola-Adams, 1993), leading to a percentage of approximately $11 \%$ for the crown biomass in the old plantations under study (with a plant density of 33 trees ha $^{-1}$ ). This is higher than the results of the 8 measured crowns $(7.2 \%)$, possibly because these trees were on average less vital. The exact age of the 8 sample trees is not known. Although the trees reach comparable heights, their DAB is always inferior to the mean DAB in the old plantations. Thus, the real crown portion for old limba plantations is most likely higher than $7 \%$ but no more than $11 \%$ in vital trees.

The range of AGB estimates based on field data and existing models (Eqs. (2)-(5)) is quite large (108 to $144 \mathrm{Mg} \mathrm{ha}^{-1}$ ). Without weights and direct measures of the specific gravity, it is difficult to decide which method should be used. Therefore, the range of AGB estimates will be compared with previous studies.

In comparison to most African natural forests (Tab. V) (Brown, 1997), the stored AGB of limba plantations is low. The estimated planned AGB (52 trees ha $\left.{ }^{-1}\right)$ is slightly smaller than the AGB of natural forest in the Luki Biosphere Reserve before silvicultural treatment (Couralet, pers. comm., 2008).

Unfortunately, other biomass estimates for old plantations are rare. Therefore, comparisons could only be made with younger plantations. Ola-Adams (1993) proves that the largest density of limba trees results in the largest stand biomass. Most teak plantations (Kraenzel et al., 2003; Ola-Adams, 1993) and pulp and fuelwood plantations with Acacia spp. and Eucalyptus spp. accumulate AGB at a faster rate than limba plantations (Bernhard-Reversat et al., 1993; Forrester et al., 2004). Thus, the old limba plantations with only 33 trees $^{-1}$ are less favourable for biomass and carbon storage.

A higher planting density for limba trees would increase the AGB and carbon stored (as confirmed by Ola-Adams 1993) but a study on the trade-off between commercial and conservation issues is necessary to determine which planting density still produces trees with an acceptable DAB and quality for industrial processing. Kalonji (1968) concluded that small planting distances $\left(5 \times 5 \mathrm{~m}\right.$ or 400 trees ha $\left.{ }^{-1}\right)$ result in closed stands with excellent natural pruning and straight stems. Limba plantations with large $(12 \times 12 \mathrm{~m})$ or intermediate planting distances of $4 \times 8 \mathrm{~m}\left(313\right.$ trees $\left.\mathrm{ha}^{-1}\right)$ showed more stem deformations and were suppressed by natural secondary species. Nevertheless, when plantations with 
Table V. AGB estimates in tropical plantations and natural forests (list of other studies on AGB by several authors, with indigenous and exotic species and important influences like density and age. Comparison with the current results is based on this table).

\begin{tabular}{|c|c|c|c|c|c|c|c|}
\hline Forest type & Country & $\begin{array}{c}\text { Density } \\
\left(\mathrm{ha}^{-1}\right)\end{array}$ & $\begin{array}{r}\text { Age } \\
(\mathrm{y})\end{array}$ & $\begin{array}{c}\text { Tree AGB } \\
(\mathrm{Mg})\end{array}$ & $\begin{array}{c}\text { Stand AGB } \\
\left(\mathrm{Mg} \mathrm{ha}^{-1}\right)\end{array}$ & $\begin{array}{l}\text { AGB increment } \\
\left(\mathrm{Mg} \mathrm{y}^{-1} \mathrm{ha}^{-1}\right)\end{array}$ & Author \\
\hline \multirow[t]{3}{*}{ Limba plantations } & \multirow[t]{3}{*}{ Nigeria } & 3086 & 13 & $<0.1$ & 127.7 & 9.8 & \multirow{3}{*}{ Ola-Adams (1993) } \\
\hline & & 1276 & 13 & 0.1 & 112.0 & 8.6 & \\
\hline & & 269 & 13 & 0.3 & 77.0 & 5.9 & \\
\hline Nauclea diderrichii plantations & Nigeria & 496 & 30 & 0.6 & 279.1 & 9.3 & Onyekwelu (2007) \\
\hline Teak plantation & Panama & 624 & 20 & 0.3 & 209.0 & 10.5 & Kraenzel et al. (2003) \\
\hline \multirow{3}{*}{ Teak plantations } & \multirow{3}{*}{ Nigeria } & 2551 & 18 & 0.1 & 275.1 & 15.3 & \multirow{3}{*}{ Ola-Adams (1993) } \\
\hline & & 1189 & 18 & 0.3 & 360.1 & 20.0 & \\
\hline & & 638 & 18 & 0.3 & 199.5 & 11.1 & \\
\hline Acacia mearnsii plantation & Australia & 1515 & 11 & $<0.1$ & 75.8 & 6.9 & Forrester et al. (2004) \\
\hline Acacia sp. plantations & Rep. of Congo & 698 & 7.5 & 0.1 & 94.6 & 12.6 & Bernhard-Reversat et al. (1993) \\
\hline
\end{tabular}

intermediate planting distances were managed, they had the highest DAB and bole height (Kalonji, 1968). Kalonji (1968) conducted his study in the same area and the same species as in the current study. So adapting Kalonji's intermediate planting distances with a management plan (as proposed by Marien and Mallet, 2004), could promote diversity (natural occurrence of secondary species) as well as creating larger commercial stand volumes and more AGB and carbon storage.

\subsection{Conclusion and perspectives}

The planned commercial volume for the final exploitation was not entirely realized, especially due to the low density. Still, individual commercial volumes exceeded the planned values, while $80 \%$ of the planned stand volume is present in the plantations. Thus, the mature limba plantations are quite successful with regard to the initial goals. Looking at commercial volume and the production of quality timber with merchantable dimensions, limba can compete with other indigenous species (e.g. Terminalia ivorensis, Aucoumea klaineana) and also teak plantations of the same age, having the advantage of larger merchantable heights and less intensive management interventions. Other exotic species as Eucalyptus spp. and Pinus caribaea Morelet have higher production rates, but can not be used for the same applications as limba and teak. In Central Africa, where the means for an intensive management of exotic plantations are often absent, indigenous species like limba will continue to play an important role due to their natural pruning capacities, the absence of infections and the ease of installing tree nurseries. In addition, the mature limba stands provide a sufficient volume production to lower the pressure on the surrounding natural forests.

Limba plantations store AGB, including carbon (especially in their stems due to the large merchantable height and small crowns), but are not preferred when sequestration is the main goal. In this case, Nauclea diderrichii is the preferred indigenous species (unpubl. data, Onyekwelu, 2007), next to exotic species as teak, Eucalyptus spp. and Acacia spp.

Homogeneous plantations are still installed but regarding the public pressure on the Congolese limba plantations, it is advisable to add other secondary species -already naturally present- creating mixed plantations (e.g. Albizia ferruginea (Guill. and Perr.) Benth., Musanga cecropioides $\mathrm{R}$. Br. ex Tedlie and Petersianthus africanus (Welw. ex Benth. and Hook. f.) Merr.). Dupuy and Mille (1993) wrote a comprehensive manual on the association and compatibility of species (e.g. Terminalia superba and Triplochiton scleroxylon), the comparative growth and the silvicultural consequences of mixed African plantations. Mixed plantations can also store a larger amount of volume, AGB and carbon compared to homogeneous plantations (Forrester et al., 2004). Within a sustainable management plan, secondary species could be used at the local and national scale (sustainable livelihood, charcoal), leaving limba for industrial applications and export. Additionally, limba trees will quickly create a forest climate and, together with this, optimal conditions for the germination of tree species of climax forests.

Acknowledgements: This research project is funded by a $\mathrm{Ph} . \mathrm{D}$. grant of the Flemish Interuniversity Council (VLIR). We would also like to thank the teams of WWF DRC, WWF Belgium, SOFORMA and the ERAIFT (École Régionale post-universitaire d'Aménagement et de gestion Intégrés des Forêts et Territoires tropicaux) for their financial support and their guidance throughout the fieldwork. Special thanks goes out to Laurent Nsenga, Geert Lejeune, Bruno Pérodeau and Prof. Shango Mutambwe, whose efforts substantially facilitated our field work campaigns. The authors also wish to thank the Fund for Scientific Research-Flanders (FWO-Belgium) for the postdoctoral funding granted to Jan Van den Bulcke. 


\section{REFERENCES}

Beghagel I. and Monteuuis O., 1999. À propos du séminaire: site, technology and productivity of teak plantations. Chiang Mai, Thaillande, 26-29 janvier 1999. Bois For. Trop. 261: 70-79.

Bernhard-Reversat F., Diangana D., and Tsatsa M., 1993. Biomasse, minéralomasse et productivité en plantation d'Acacia mangium et $A$. auriculiformis au Congo. Bois For. Trop. 238: 35-44.

Brown S., 1997. Estimating biomass and biomass change of tropical forests: a primer. FAO For. Pap. 134.

Chave J., Riéra B., and Dubois M.-A., 2001. Estimation of biomass in a neotropical forest of French Guiana: spatial and temporal variability. J. Trop. Ecol. 17: 79-96.

Chave J., Andalo C., Brown S., Cairns M.A., Chambers J.Q., Eamus D., Fölster H., Fromard F., Higuchi N., Kira T., Lescure J.P., Nelson B.W., Ogawa H., Puig H., Riéra B., and Yamakura T., 2005. Tree allometry and improved estimation of carbon stocks and balance in tropical forests. Oecologia 145: 87-99.

Dupuy B. and Mille G., 1993. Timber plantations in the humid tropics of Africa, Rome, FAO, 192 p.

Dupuy B., Maître H.-F., and Kanga A.N., 1999. Table de production du teck (Tectona grandis). L'exemple de la Côte d'Ivoire. Bois For. Trop. 261: 5-16.

Duveiller G., Defourny P., Desclee B., and Mayaux P., 2008. Deforestation in Central Africa: estimates at regional, national and landscape levels by advanced processing of systematicallydistributed Landsat extracts. Remote Sens. Environ. 112: 1969-1981.

Elias M. and Potvin C., 2003. Assessing inter- and intra-specific variation in trunk carbon concentration for 32 neotropical tree species. Can. J. For. Res. 33: 1039-1045.

Evans J. and Turnbull J., 2004. Plantation forestry in the tropics, 3rd edition. Oxford University Press. Oxford, 467 p.

FAO, 2005. Global Forest Resources Assessment 2005: main report. FAO Forest Paper 147, FAO, Rome, 350 p.

Fonweban J.N. and Houllier F., 1997. Eucalyptus saligna au Cameroun. Tarif de peuplement et modèle de production. Bois For. Trop. 253: 21-36.

Forrester D.I., Bauhus J., and Khanna P.K., 2004. Growth dynamics in a mixed-species plantation of Eucalyptus globulus and Acacia mearnsii. For. Ecol. Manage. 193: 81-95.

Groulez J. and Wood P.J., 1984. Monographie du Terminalia superba. CTFT, Nogent-sur-Marne, 85 p.

Humblet P., 1946. Aménagement des forêts climatiques tropicales au Mayombe. Bull. Agric. Congo Belge 37: 15-87.

Kalonji V., 1968. Étude de l'écartement de plantation du limba au Mayombe. M.S. thesis, Université Lovanium de Kinshasa, Kinshasa, $62 \mathrm{p}$.

Kraenzel M., Castillo A., Moore T., and Potvin C., 2003. Carbon storage of harvest-age teak (Tectona grandis) plantations, Panama. For. Ecol. Manage. 173: 213-225.
Lamprecht H., 1989. Silviculture in the tropics: Tropical forest ecosystems and their tree species - Possibilities and methods for their longterm utilisation. German Technical Cooperation, Eschborn, 296 p.

Lugo A.E., 1992. Comparison of tropical tree plantations with secondary forests of similar age. Ecol. Monogr. 62: 1-41.

Mabela M.M., 1978. Dynamique des limba en sylvo-bananier au Mayombe (République du Zaïre). M.S. thesis, Université Laval, Laval, $90 \mathrm{p}$.

Marien J.-N. and Mallet B., 2004. Nouvelles perspectives pour les plantations forestières en Afrique centrale. Bois For. Trop. 282: 67-79.

Mukendi M.W., 1973. Étude dans 1 es blocs sylvo-bananiers de la Station forestière de l'INERA-Luki et du chantier forestier de l'Etat au km 28 (Mayombe). M.S. thesis, Université nationale du Zaïre, Kinshasa, $107 \mathrm{p}$.

Navar J., 2009. Biomass component equations for Latin American species and groups of species. Ann. For. Sci. 66, 208.

Ola-Adams B.A., 1993. Effects of spacing on biomass distribution and nutrient content of Tectona grandis Linn. f. (teak) and Terminalia superba Engl. and Diels. (afara) in south-western Nigeria. For. Ecol. Manage. 58: 299-319.

Onyekwelu J.C., 2007. Growth, biomass yield and biomass functions for plantation-grown Nauclea diderrichii (de wild) in the humid tropical rainforest zone of south-western Nigeria. Bioresour. Technol. 98: 2679-2687.

Pendje G., 1993. Croissance et productivité de deux essences forestières plantées au Mayombe, Zaïre: le limba (Terminalia superba Eng. et Diels) et le bilinga (Nauclea diderrichii (De Wild) Merrill). GeoEco-Trop 17: 101-120.

Rondeux J., 1999. La mesure des arbres et des peuplements forestier. Les presses agronomiques de Gembloux, Gembloux, $521 \mathrm{p}$.

Rowell R.M., 2005. Handbook of wood chemistry and wood composites. Taylor \& Francis, Boca Raton, 487 p.

Sands R., 2005. Forestry in a global context. CABI Publishing, Trowbridge, $262 \mathrm{p}$.

Sarlin P., 1963. La pédologie forestière dans les pays tropicaux - La forêt et le sol. Bois For. Trop. 88: 7-22.

Tausch R.J. and Tueller P.T., 1988. Comparison of regression methods for predicting singleleaf pinyon phytomass. Great Basin Nat. 48: 39-45.

Tutula P., 1968. L'enrichissement de la forêt du Mayombe en Terminalia superba Engl. et Diels par le système sylvo-bananier. M.S. thesis, Université Lovanium de Kinshasa, Kinshasa, 75 p.

Víquez E. and Pérez D., 2005. Effect of pruning on tree growth, yield, and wood properties of Tectona grandis plantations in Costa Rica. Silva Fenn. 39: 381-390.

White F., 1983. The vegetation of Africa. UNESCO, Switzerland, $356 \mathrm{p}$.

Woodcock D.W., Dos Santos G., and Taylor D., 2000. The buttressed blue marble tree: wood and growth characteristics of Elaeocarpus angustifolius (Elaeocarpaceae). Ann. Bot. London 85: 1-6. 